\title{
AGRICULTURAL INPUT MOBILIZATION
}

\section{FOR AFGHANISTAN}

\author{
Prepared For \\ Office of the AID Representative \\ Islamabad
}

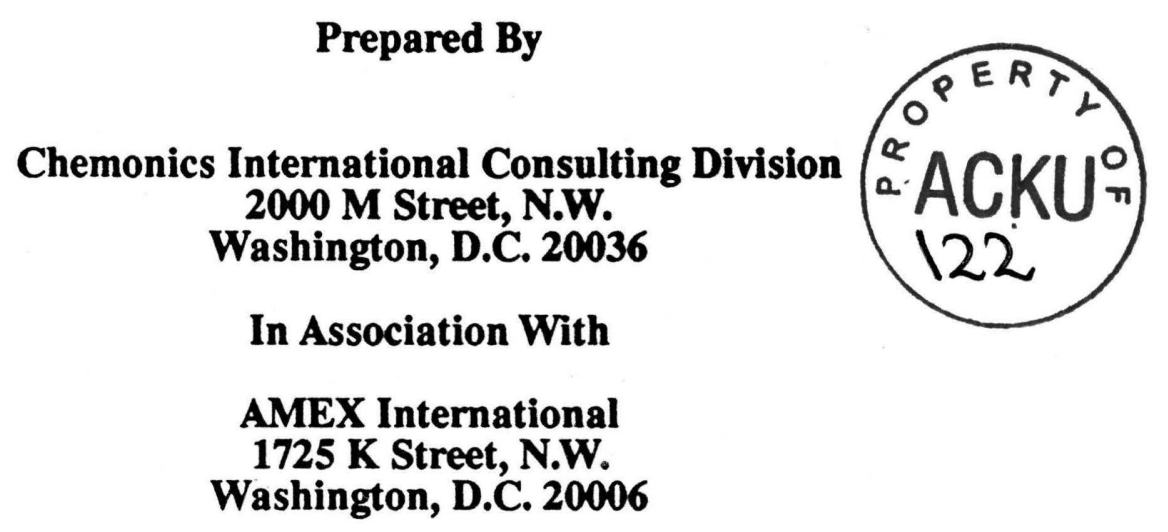

October 20, 1988 
I. INTRODUCTION AND SUMMARY 1

A. Financing Mechanism 1

B. Distribution Mechanism 2

C. Other Material 5

II. BACKGROUND AND SETTING 6

A. Agriculture Situation in Afghanistan 6

B. Immediate Problem and Target 7

III. FERTILIZER DEMAND 8

A. Historical Outlet Demand 8

B. Computation of Demand Based on Need 10

C. Economic-Price Considerations 12

D. Agricultural roduction Constraints 13

$\begin{array}{ll}\text { IV. FERTILIZER SUPPLY } & 15\end{array}$

A. Introduction 15

B. Fertilizer Sources 16

D. Eagging 22

E. Karachi Port $\quad 24$

F. Inland Freight 24

G. Border Terminal 26 .

H. Cross-Border Transportation 29

v. DISTRIBUTION 33

A. A Cross-Eorder Distribution System 33

Annex \#1 - The Afghan Fertilizer Company 39

Annex \#2 - U.S. Froducers/Exporters of DAF \& Urea 42

Annex \#3 - Other Free World Froducers/Exporters 43

Annex \#4 - Clearing/Forwarding Agents 44

Annex \#5 - Pakistan Producers of Urea 45

Annex \#6 - Fersons Contacted 46 
SECIION_I

\section{INTEQDUSTION_AND_SUMMAEY}

This paper proposes a systern unjerwhich USAID-financed tertilizer, seeds and other agriculcural inputs can be procured and distributed within the i iberated crescent of Afghanistan ir a way which will (1) be independent of the fabul Government, (2) mate maximuin luse of the private sector and the lessons learned from the Afghan Fertilizer Company experience prior to the war and ( $)$ will be easily transferred to fabul and a nation-wide input distribution firogram (a new AfC) once this becomes possible.

\section{A. Einancing Hechanism}

Chemonics believs that there are two basic mechanisms for the procurement or supply of fertilizer and other inputs which might be suitabie for the first year or two of the program. They are (1) a grant program and (2) a commodity inport program. We believe it is not possible to depend solely on a CIF, becalse it will be necessary to "give away" a significant portion of the fertilizar handled. Therefore, the viable options are (1) a single grant progran with a mixture of cash sales and "give away" commodities to the returning refugees and displaced persons, arid (2) a dual program, in which part of the fertilizer would be provided under the CIF, for cash sales to generate local currency reflows, and a grant program which would cover only the "give away" commodities. In both cases, it. wauld be possible to add in a credit program, and apply it to both the sales element and ultimately the "give away" element, thus eventually changing the "give away" to a credit program.

Chemonics favors, for the first two years at least, a single AID-financed grant program which would include a targeted ("coupon") give away program to those rieeding it, and a cash sales program for those farmers in the area needing fertilizer and willing to purchase it or a cash basis. The cash generated from the sales wouid be used to support the operations of the distributon agericy. (see below)

The CIF is not favored because the potential local currency generation is very small, and would not, in our view, justify going through the complexities of a CIF. The basic problem is that the present, Governemt-run AFC is seiling fertilizer in Afghanistan at a subsicized price of Afs. bou per $50 \mathrm{~kg}$ bag of urea and fifs.760 tor DAF. This worlis olit to 73.00 and $\$$. 50.50

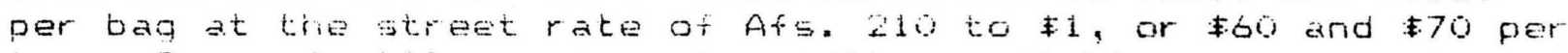
ton. Sirce fertilizer is not. readily available at this price, we assume that the demand is such that USAID-financed fertilizer could be sold for twice the "official, subsidized price, or fiaj 
and $\$ 140$ per ton or even higher. We estimate that the cost of getting the fertilizer from Falistan to Afghanistan, including dealer margins, is $\$ 80$ per ton. This would allow a reflow, after covering delivery and sales costs or margins, of the Af. equivalent of $\$ 40$ and $\$ 60$ per ton. The procurement cost of the fertilizer in Fatistan under such a program is, say, 160 per ton for urea and at least $\$ 240$ per ton for DAF'. Thus the reflows would be, for urea, $\$ 40$ on a procurement outlay of $\$ 160$ $(25 \%)$ and $\$ 60$ on an outlay of $\$ 240(25 \%)$, not very attractive by CIF standards. Note that even these modest reflows depend on procurement in Fakistan; if offshore procurement were required, the transport costs and margins would eat up more of the sales revenues, and the resulting smaller reflows would be a very small percentage of the higher procurement cost. Finally, Chemonics believes that the reflows possible from the sales part of the grant program, used to help finance the distribution operation, would probably be larger on a per ton basis than those of the CIF program.

Thus we propose a straight grant program with a portion set aside for give away (to support the returning refugees) in the first year of each refugee's return, followed by a credit program, and a portion set aside for cash sale to those not qualifying for the "give away". A credit sales program would be set up as soon after the first year as possible.

\section{E. Distribution Mechanism}

Based on Chemonics' long experience in Afghanistan with the Afghan Fertilizer Company, our extensive interviews during the current assigriment and the guidelines provided by AID/FEF' $s$ office, we propose the following basic mechanism. We would create what we call the AIME, or Agricultural Input Mobilization Entity, charged with procurement, shipping and wholesale (and occasional) retail distribution of fertilizer originating in Fatistan or offshore via Fakistan. AIME would be governed by a Supreme Council, which, among other things, would set policy including determination of who is eligable to receive "give away" fertilizer and seed. The entity would be managed by a team of expatriate specialists provided by a private firm under contract or grant financed by AID/FEF, and staffed by Afghan and Fakistani specialists recruited by the management team.

Candidates would doubtless include former employees of the AFC. AIME would depend mostly on private retailers for retail sales and to a limited degree on private wholesalers, but would have itself the full range of capatilities including direct AIME retailing to ensure that all parties maintain reasonable performance standards and margins.

These basic parameters of the program have been selected as the best approach to (1) ensuring the availability of fertilizer and other iruputs of the returning refugees and displaced persons, and other farmers in the liberated areas, and (2) creating a distribution mechanism which can be most readily expanded when the time comes. 


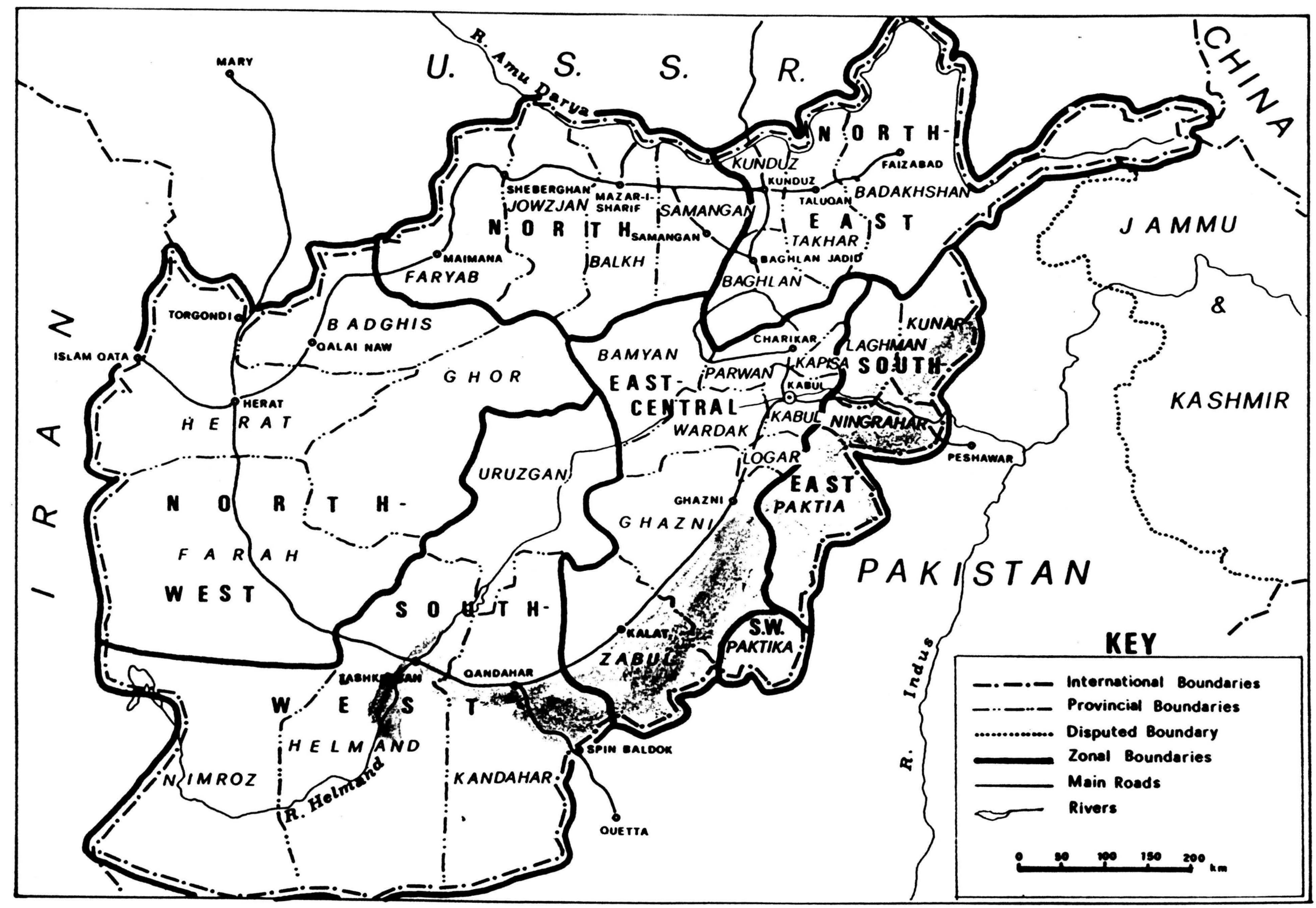




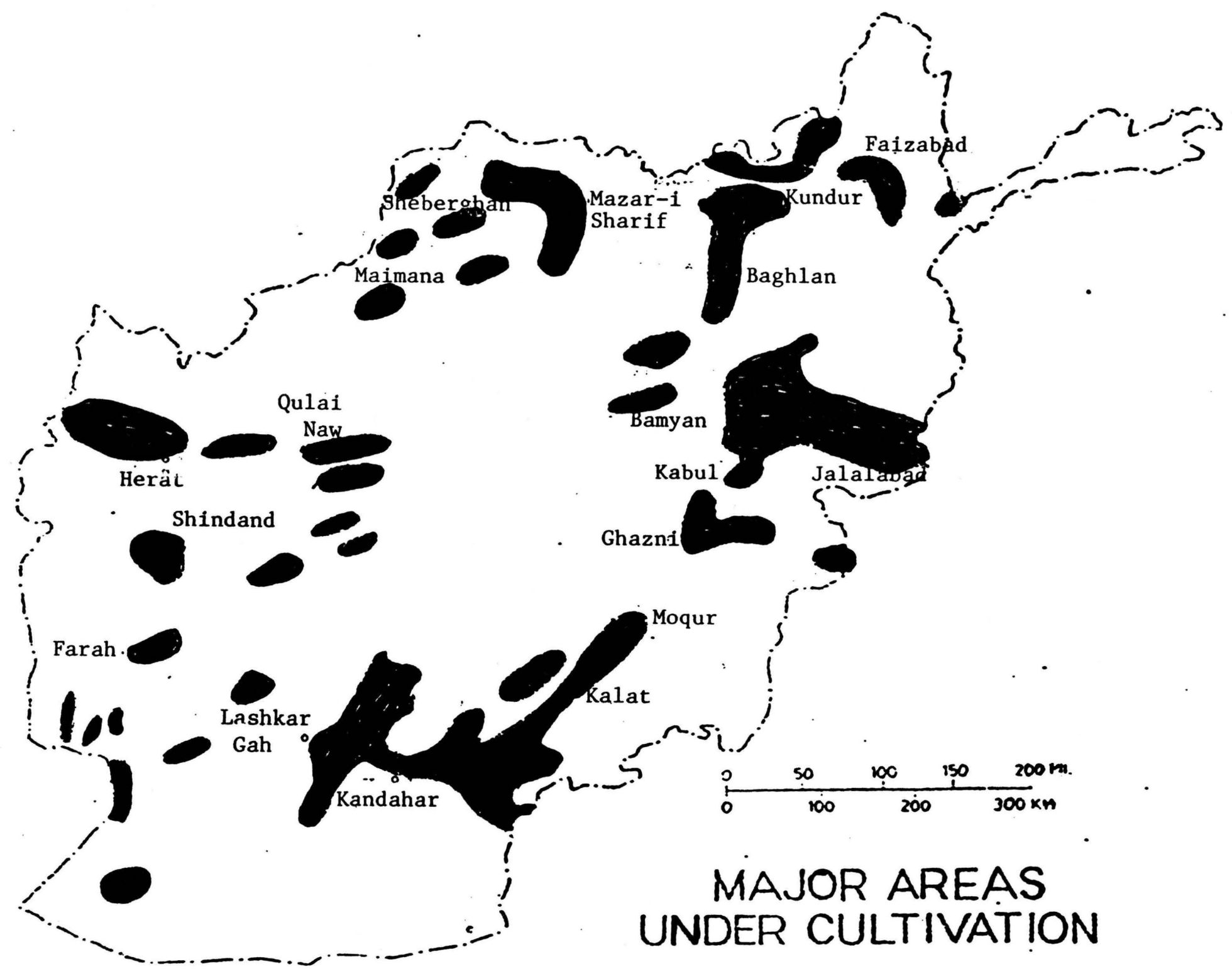


Details are provided in the following sections, mainly section five.

c. Other Material

The report also provides considerable information on the marlet for fertilizer and, to a lesser extent, other inputs in the 1 iberated areas of Afghanistan, which serves, among other things, to justify a ininimum first year 20,000 MT program, and considerable information and analysis of the supply situation, including transportation and storage. 


\section{SEEIION_II}

\section{BACKEGEQOUND_AND_SEITING}

This section outlines briefly the backsgound and setting for the proposed agricultural input activity. Most of this material is available in detail in other documents, so it will be provided in summary form here and in the following sections of the report as needed.

\section{A. Agricultural Situation in Afghanistan}

Afghanistan is traditionally a highly agricultural country. Although the terrain is rugged, most of the country 1 ies in the temparate zone and, between rainfall and snow-fed rivers, has reasonable water supplies to support both rainfed and irrigated agriculture. Eefore the war, in spite of the country's many problems, the Afghanistan was approaching net food self sufficiency. This self sufficiency was engendered in significant part by the use of fertilizer on most of the irrigated wheat, grapes and other crops. Fertilizer availability was, from 1972 onward, assured by the quasi-private Afghanistan Fertilizer Company.

The current situation, very briefly, is that Afghan agriculture has been severely damaged by the war, with the disruption of normal services, destruction of irrigation systems and roads, deteriorated availability of inputs and, of course, the departure of a major portion of the agricultural population as refugees or war casualties. On the other hand, the reduction in population numbers needing to be fed has reduced the food requirements. With respect to inputs, the Afghan Fertilizer Company has remained in being, but has been made into a fully Government entity, highly policitized. AFC reportedly provides fertilizer, with considerable logistical difficulties, only or mainly to people acceptable to the party. Available distribution figures from the AFC suggest that quanties distributed in recent years by the Company are higher than before the war, a statistic which should be taken with some skepticism. The main rationale supporting the possible validity of these figures is that, given the deterioriation of the overall farming system in the country, only heavier than usual applications of fertilizer could maintain production at anything like acceptable levels.

Further, it appears that the Fiussian built and operated urea plant at Mazar-1-Sharif is not only still operating, but doing so at about 120,000 MT per year, considerably above the original design capacity. Assuming this to be the case, it is an enormous potential advantage for Afghanistan's eventual normalization and recovery of its agricultural sector. As 
discussed in detail in the report, there are several elements to this situation, including the possibility that significant qualtities of the urea are being "exported" to the Soviet Union.

Whatever the truth in detail, the basic fact is that Afghanistan's agricultural economy still functions, but with numerous deficiencies which must be dealt with if the country is to return eventually to net food self sufficiency. Improved availabilities of fertilizer, quality seed and other imputs, all over the country and to all farmers, are a key to this recovery.

Fertilizer and seed are especially important. Before the war, the effectiveness of fertilizer, particularly urea and DAF, was graphically demonstrated in the context of Afghanistan irrigated agriculture, especially wheat, grapes and cotton (the last two major cash crops.) With respect to wheat, it was clearly demonstrated that importing, or producing and using fertilizer, which would increase wheat production at a ratio of approximately $4 \mathrm{kgs}$ of wheat to $1 \mathrm{~kg}$ of fertilizer was much preferable to importing wheat. With respect to seed, it is generally believed that the Afghan seed stock has not been adequately renewed since 1980 , that the farmers have been replanting the same germplasm for many years and that, therefore, the seed quality is very poor which leads to poor yields. It will be riecessary to ensure that improved seed, of available (in Falsistan) new Mexipal varieties, are made available along with the fertilizer. Fertilizer without improved seed, or the reverse, would sharply reduce the effectiveness of these key inputs.

E. Immediate Froblem and Target

Afghan agriculture is obviously faced with global problems, as discussed just above. Litimately, ways will have to be found, as part of the overall recovery effort, to ensure, among other things, the availability of agricultural inputs in all parts of the country and to all classes of farmers. However, the immediate problem to be dealt with through USAID-financed efforts invalves input requirements in the liberated areas and, especially, for the returning refugees. The problem, and the objective, is twofold. First, to give the refugees and displaced persons both the ability to return successfully and the incentives to do so. Secondly, to attempt to ensure that Afghanistan, and especially the liberated areas (not traditionally food surplus areas) will be able to grow enough food to feed the entire population of the areas, both the existing population and the returnees.

This dual target, direct refugee assistance and food adequacy in the liberated areas, leads to the dual program which is presented extensively in subsequent sections of the report. 


\section{FEEEIILIIZEEE__DEMEND}

The purpose of this section is to determine a rational level or volume for a program of supplying fertldizer to the liberated crescent of Afghanistan. The issue can be looted at in two ways. First, how much fertilizer will be needed to meet the two objectives of the project: (1) to assist, and induce, the refugees in Fakistan to return to Afghanistan and begin farming their lands again, and (2) to ensure that an adequate supply of food $c$ an be grown in the area to feed both the existing population and the returning refugees.

Data is very weat to support any analysis of demand in this situation. Accordingly, we strongly recommend that, after the analysis, a rather modest target figure be selected to ensure that the area will be able to absorb the product made available.

In developing demand projections, two factors were predominant:

- The historical offtake of fertilizer.

- The food reeds of the returning refugees.

Much of the analysis necessarily deals with the whole country. However, as is discussed throughout this report, the area of interest in the liberated crescent, or area clearly under mujhadin control, which is an area along the Faisistin border to a depth of about 200 to $250 \mathrm{~km}$.

\section{A. Hítorical out 1 et pemand}

On the following page, in Table I, we provide the data reported by the Afghan Fertilizer Company (AFC) on its sales from 1972 through 1986. The product deseribed is a min of locally produced urea (Mazar-i-sharif plant) and imported phosphatic fartilizers, mainly DAF. The data spans the period when AFC was operated as a quasi-private company assisted by a technical assistance team from Chemonics, up to 1979, and the period under the Kabul Government thereafter. During the pre-war period, the ratio between urea and DAF, by product weight, tended to be 2: 1, a ratio based on agronomic recommendations for tine major crops. Fre-war, phosphate fertilizer imports were from the free world, since 1980 mostly from the Soviet bloc.

The table shows that, apparently, AFC sales tended to increase after the war started. We also unjerstand that the Mazar plant has continued to operate since the war started and now is producing 120,000 MT, which is above the desigh capacity. It is entirely possible that the 120,000 MT of urea was distributed in Afghenistan along with whatever phosphate the Soviets were able to supply from the outside. The data suggests that, in 1986, some 50, oo MT of phosphate fertilizer was suppiied, keeping the 
Table it: Feported fertilizer sales by Afghan Fertilizer Company (AFC) by Year

Year

1972

1973

1974

1975

1976

1978

1979

1980

1981

1982

1983

1984

1985

1986
Sales of Eertílizer (in Metríc Tong)

$$
\begin{array}{r}
44,000 \\
63,000 \\
70,000 \\
84,000 \\
100,000 \\
103,000 \\
94,000 \\
104,000 \\
98,000 \\
115,000 \\
121,000 \\
146,000 \\
152,000 \\
170,000
\end{array}
$$

Source: $\overline{A F C}\left\langle\overline{2} \bar{\gamma}^{-}\right.$via Dr. Wakil's memo of July 11,1988 
ratio between iN and $F$ close to the historical levels. We also understand that. in 1987 , the total deliveries dropped to $135,000 \mathrm{MT}$. Since we have hearo nothing to indicate a fall off in urea from Mazar, this suggests that the Soviets fell very short in their $F$ deliveries, which squares with anecdotal information that the Soviets reneged on their commitments in this regard and that there have been shortages of $F$.

The above all pefers to the global demand in ffghanistan. We are interested inainly in the liberated crescent. We do have one informally obtained report from the AFC which breaks down sales by province, and gives an opportunity to add up the sales from those provinces in the crescent. In doirig 50, we find that $40 \%$ of the phosphate fertilizer reported and $50 \%$ of the urea was sold in the crescent, or a combined share of $47.6 \%$. The total figures in this report, interestingly, were considerably lower than in other reports: about 87,000 MT for the cauntry as a whole (1987-88). The total sales in the crescent were 40,000 MT.

Looking at historical data, the following cover an area which is similar to but larger than the crescent, the old kandahar and Kabul AFC districts.

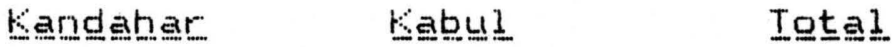

$\begin{array}{lllll}1973-1975 & 22,000 \mathrm{MT} & 24,000 \mathrm{MT} & 46,000 \mathrm{MT} \\ 1976-1979 & 31,000 \mathrm{MT} & 32,000 \mathrm{MT} & 63,000 \mathrm{MT}\end{array}$

Thus one could argue that the historical requirement for the area is $60,000 \mathrm{MT}$, and the current figure is $40,000 \mathrm{MT}$, reduced by the fact that the crescent is somewhat smalier than these two former AFC districts, the reduction in agriculcural population and all of the other problems facing agriculture in the area.

Ferhaps the most valuable aspect of all of the current AFC data is the indication that, in spite of all the problems, Afghan farmers are interested in using fertilizer and sufficiently knowledgable about it to do so when it is available. The very low subsidized prices charged by the Government (Afs. bog/bag, equal to about $\$ 60$ per ton of urea) doubtless contributes to the significant quantities demanded. Still, given the data, we believe that the crescent area may eventually have a maximum outlet demand for up to $80,000 \mathrm{MT}$ of fertilizer.

\section{B. Computation of Demand Eased on Need}

The other way to look at demand is to base it on an analysis of need. There are obviously many farmers remaining in the crescent. They require fertilizer and, reportedly, some of them at least are receiving it, especially those on which the party looks with favor. Indeed, if the AFC is delivering the tonnages claimed, a considerable amount must be getting into the area, in spite of the difficulties in moving it from Mazar, north of the Salang pass, to the south. Fieports indicate that fertilizer is available in the area, in spite of recent reports of shortages of $F$. We could say that the existing sources, the AFC, is supplying the existing farmers, aithough we doubt that tinis is entirely true.

In short, we believe that a certain amount of additional fertilizer, from sources in Fakistan, would be purchased by the existing farmers in the area to supplement whatever they are getting from the Soviet Uniori. Since these farmers are "established", they would be good candidates for 
Table \#2 : Fertilizer LIfting by Frovince in Afghanistan during $1987 / 1988$

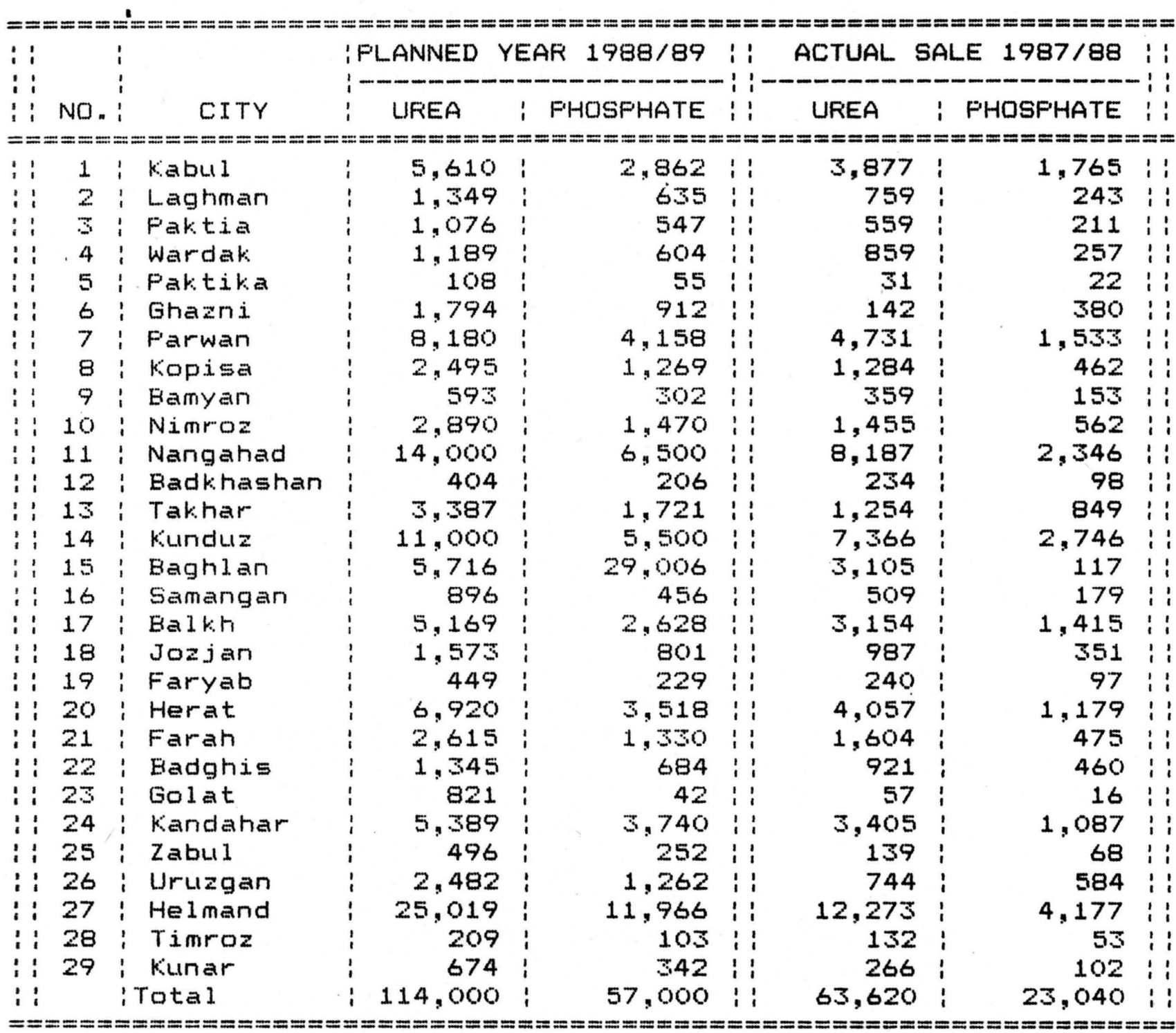

Source: Obtained informally by Chemonics 
cash sales rather than the "give away" program planned. We would be comifortable in estimating between 5,000 and 10,000 MT in this category, more heavily weighted toward DAF than is usually the case because of the difficulty in obtaining F fertilizer from the Soviet bloc in recent. times. This estimate is also based on a sales price for fertilizer to established area farmers of at least Afs. 1,400 per bag of DAF, double the official price. This is possible only because of the believed shortages of phosphate fertilizer at the present time.

If the premise that the farmers who have remained in Afghanistan during the war continue to have access to fertilizer and to produce, more or less, enough food to feed themselves is valid, it is the requirements of the returning refugees that must be addressed. This is so because (1) they are the main target of the program and (2) they will need "give away" fertilizer which will obviously not be available from the AFC.

The basic computation of need for the refugees is quite simple. We estimate that each person requires $170 \mathrm{~kg}$ of grain per year. If a $\mathrm{kg}$ of fertilizer is needed to produce between 3 and $4 \mathrm{~kg}$ of wheat, each returning refugee would need to be supported by about $50 \mathrm{kgs}$ of fertilizer, or, rather conveniently, one bag. In practical terms, one family of $s i x$ would need six bags of fertilizer. Of course, the mix would still be between $N$ and $F$, at a ratio of $2: 1$, so this would mean four bags of urea and two bags of DAF.

The amount of fertilizer needed to support subsistance farming very simply becomes a function of the number of refugees one expects, or wants, to return and take up farming each year. One miliion refugees would require 50,000 MT of fertilizer to grow the subsistance food crop.

Although it might well be desirable to induce one million refugees to return to Afghanistan this year or next, we do not think one can plan on such a figure. Ferhaps 400,000 refugees might be expected in the first year, and 600,000 the second. Fertilizer for this group would be 20,000 MT for the first year and $\$ 0,000 \mathrm{MT}$ the next.

So, using these very rough data, we have a supplemental requirement for the existing population of between 5,000 and 10,000 MT of fertilizer in the first year, and for the returning refugees, based on 400,000 people returning, of about 20,000 MT. This brings the total of 25,000-30,000 MT. However, given all of the constraints, and in the interest of being conservative, we prefer to reduce the total target amount to 20,000 MT. The motivation for this conservative approach is, in part, a belief that even this tonnage would be a strain on the delivery system in the first year. Given the apparent shortages of phosphate in the area, we would expect to depart from the usual 2:1 ratio and import a 1:1 ratio of urea to DAF'.

\section{Economics-Frice Considerations}

Although we believe our estimated figure for effective demand for refugee and supplemental sale fertilizer in the crescent is low, and can easily be absorbed under the proposed program, we believe that, for the long pull, more rigorous examination of the economics of fertilizer marleting and sales would be justified. This is especially true because 
we propose that the "give away" period be very short, only the first year, afterwhich the returned refugees would be expected to buy their fertilizer for cash or credit.

Easically, farmer clecision to buy and luse fertilizer is based on the cost benefit of so doing. The fact that research data indicates a return of $4 \mathrm{kgs}$ of additional wheat for each $\mathrm{kg}$ of fertilizer used in accordance with recommendations males the calculation relatively easy. Under current conditions in Afghanistan, with everthing in short supply, the 4: 1 ratio may, in fact, be considerably less. However, for this calculation, we use it.

The cal'culation is as follows:

One $\mathrm{kg}$ of fertilizer will produce four $\mathrm{kg}$ of wheat. The prices of wheat and urea and DAF are as follows:

Official prices: Urea Afs. $600 / 50 \mathrm{~kg}$ or about $\$ 60 / \mathrm{MT}$ DAF', Afs. $700 / 50 \mathrm{~kg}$ bag or $\$ 70 / \mathrm{MT}$.

Wheat Afs. 200/seer equals about $\$ 130 / \mathrm{MT}$

With one $\mathrm{kg}$ of fertilizer producing $4 \mathrm{~kg}$ of wheat, at official prices $\$ 60$ worth of urea produce $4 \% \$ 130$ equals $\$ 520$ worth of wheat. This is a cost/benefit ratio of almost 9:1, (the farmer gets Afs. 9 back for each Af. used for fertilizer. Since we usually believe a return of Afs. 3 for each Af. spent of fertilizer is enough to induce farmers to invest in fertilizer, this benefit/cost ratio of $9: 1$ is far more than enough to induce farmers to purchase and use the commodity.

Even if we change several of the assumptions, doubling the price of fertilizer for the blacl: market and dropping the impact of the fertilizer from 4:1 to wheat, to 3:1. We still have $\$ 120$ in fertilizer producing $\$ 390$ worth of wheat, a cost/benefit ratio still in excess of $3: 1$. In fact, still higher fertilizer prices can be tolerated and still lead to purchase, as long as the impact $r$ atio (the amount of wheat produced for each unit of fertilizer added) does not fall much below $3: 1$ and the price of wheat remains high.

Thus, because fertilizer use appears so profitable, it could be argued that considerably more than the suggested 5,000 MT of fertilizer for purchase to supplement the AFC fertilizer could be sold in the crescent at a price of at least double the official price. However, as indicated previously, we prefer to remain conservative in our demand and program projections.

\section{Agricultural Froduction Constraints}

One of the reasons for conservatism in projecting effective fertilizer demand in Afghanistan, for the next few years, is the presence of a number of relatively severe agricultural constraints. These tend to hold down the use of fertilizer. 


\section{Seed}

The wheat varieties used in Afghanistan have degenerated and need replacement. The development of new varieties within Afghanistan willbe a long term venture. Meanwhile, good new varieties used within fakistan are regarded as suitable. The fertilizer program will need to be backed up by a program of procuring seed in Fakistan and delivering it, for sale or "give away", along with the fertilizer. At the same time, work should begin on seed multiplication and certification in Afghanistan. The proposed AIME could and should handle seed as well. Unitil and unless good seed is available along with the fertilizer, the full benefit of the fertilizer, will not be obtained.

\section{Earm Eower}

As is well known, the war has caused severe reductions in farm animal supply in Afghanistan. Other programs are gearing up to deal with this problem. Because of the long delays in breeding up the supply in Afghanistan, the programs currently involve importing animals from Falistan, the United States and elsewhere. Until the farm power supply is restored, this will be a major constraint, in effect holding down the demand for fertilizer.

\section{Irrigation water Supely}

The loss of irrigation facilities as a result of the war is also well known and current projects, including USAID-financed projects, are delaing with it as best they can. In Afghanistan, most fertilizer and quality seed is used on irrigated land; crops grown on rainfed land rarely respond enough to fertilizer to justify the cost. Therefore, continued efforts to restore irrigation facilities must go hand in hand with the inputs program if both are to be effective.

\section{Eroduction Credit}

Credit is, as always, a major problem. Once we get beyond the "give away" phase of the inputs program for the returned refugees, a credit program will be needed to support fertilizer purchases. There is no obvious way to provide the credit. The Ag Eank is still operating, but as an agency of the kabul Government and therefore not suitable for our purposes. Within a short time after the inputs program begins, AIME and other entities are going to have to develop a workable credit program. 
FERTILIZER SUF'F'Y

A. Introduction

As pointed out in section III, during 1988 and 1989 it is oniy necessary to stpply urea and DAF to Aghan farmers, and not other types of fertilizers. There are several potential sources of these fertilizers, each entailing its own combination of available handing and transport systems. The selection of the source or scurces will depend on many factors, the most important of these being:
- constraints on sourcing which may be imposed by applicable USAID procurement: rules.
- restrictions in the capacity to handle and transport fertilizers through the required systems.
- the degree to which the program can utilize sources and services within Fakistan which are largely controlled by agencies of the GOF.

\title{
from: \\ Sources of fertilizer supply are categorized as coming
}

\author{
- the United States \\ - the Free world \\ - Fakistan and Afghanistan
}

If procurement of any or all of the requirement is from off-shore Fakistan (U.S. and Free World) it will be necessary to receive these supplies in karachi and forward them via rail and/or truck to Feshawar and Chaman, which is the railhead between Glietta and the Afghan border. Terminals at Feshawar and Chaman must then handle and store significant quantities of fertilizer before they can be trucked cross-border to the areas targeted for supply in Afghanistan.

Falistan imports large quantities of DAF, some of which is

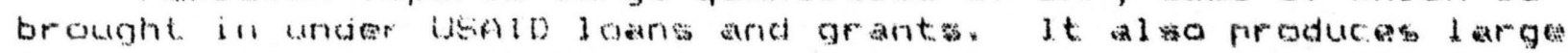
tonnages of urea. The total annual urea capacity is 1,900,000 MT in 6 factories and production in Fertilizer Year 1987 was only slightly under the total capacity figure. For reasons outlined below (Subsection B-S) we believe it is possible to procure urea from domestic producers and purchase imported DAF and/or urea from or with the help of the fertilizer Import. Department (FID, formerly FDFI). FID is responsible for procuring and forwarding all fakistan fertilizer imports. 
Sourcing the fertilizer requirement in Fakistan would substantially reduce forwarding, handling, transport and storage problems because:

0 the average inland transport distance would be reduced (in the case of urea).

- storage requirement at Feshawar and Chaman would be substantially reduced.

- FID andior the producers would normally arrange the primary transport to depots in Feshawar and Chaman.

- the necessity of handling imports in bond to the border would be eliminated.

To the extent that urea is available in the Targeted Areas from the factory in northern Afghanistan (Mazar-i-Sharif), supply of urea from other sources can be reduced correspondingly, and particularly the transport cross-border can be reduced. For reasons discussed below (Subsection B-3) we have assumed in this study that only insignificant amounts from this source willi reach the Targeted Area during 1989 and the same probabiy will hold true in 1990.

What follows is a more detailed description of the sources and the handiing and transport systems available to procure and distribute 20,000 MT of fertilizers to the Targeted Area inside Afghanistan for the crop season commencing in Detober 1989. The discussion is probably applicable to the 1990 crop season as well, when we believe around $30,000 \mathrm{MT}$ will be required in the Target Area. Eeyond 1990 many factor 3 are likely to change, particularly, the area to be supplied may expand to include other major farming areas in Afghanistan, the majority of the refugees are likely to have returned to their homes and direct procurement through new agencies in kabul may be in effect.

E. Fertilizer Sources

\section{United States Froducers}

A 1 ist of U.S. urea and DAF producers is appended at Annex \#2. In 1987 the U.S. exported 6.6 million MT of DAF which represented about $60 \%$ of all DAF traded internationally in that year. In contrast, the U.S. was a net importer of $1.4 \mathrm{milli}$ on MT of urea in that year.

As the iargest exporter of DAF, U.S. product reached al 1 major Asian marbets, including India, China and Fakistan in 1987. There would be no difficulty in sourcing the quantities required to be imported for distritution in Afghanistan ( 5,000 to $10,000 \mathrm{MT}$, in $178 \%$ in the U. 9 .. However, several factors may combine to make these imports extremely expensive. 
Rarachi Fort can handle 20,000 to 30,000 DWT vessels and fertilizer $1=$ normally received there in vessels in this size range. We project the combined tomnage of DAF and urea required in the Tar get Area in 1989 to be no more than 20,000 M. If purchased in the U.S. this would mean a minimum of two shipments, one of 10,000 to $15,000 \mathrm{MT}$ of urea and the other of 5,000 to $10,000 \mathrm{MT}$ of DAF. Freight rates for vessels of this size from U.S. ports will be approximately 50 to $80 \%$ higher than the rates for the larger vessels normaliy used.

Considering the requirement that $50 \%$ of USAID financed commodities be transported in U.S. bottoms, the already inflated rates will be increased by an additional factor of $70 \%$ to $100 \%$, unless a determination is made that no U.S. bottoms are available.

Moreover, since the U.S. is a large net importer of urea, the export price (FOB price) of urea from the U.S. Will reflect, at least in part, the average in-bound freight cost of the imports and will therefore generally be availabie for export at prices which are above internationally competitive prices. The only possible exception to this would be supply from the Unocal plant at renai, Alaska which, in effect, takes on some of the attributes of an off-shore supplier to the U.S.

A further problem, discussed in Subsection C below, arises because of the very high costs of bagging and bag handling in the U.S.

The small vessel sizes, the potentially excessive U.S. freight, and the probable need to bag at least the urea purchases in the U.S. make it certain that procurement from other international sources, or from FID and Fakistan urea producers, will be substantially less expensive.

Estimated current karachi fort landed costs from several sources are shown in Table \#3.

\section{International Eroducers}

A 1 ist of Free World countries that are producers/ exporters of urea and $D^{2}$ can be found in Annex \#3. While not complete, the major Asian exporters of urea and Free world exporters of DAF are listed.

The FOB bulk prices from Asian DAF producers (Korea, the Fhilippines and Jordani have always been in near equilibrium with the FOB buik price ex-Tampa Florida plus internationally competitive freight in Handy-sized buik carriers (approximately 30,000 DWT) into the region. When purchasing DAF in smaller vessels from asian producers the overall freight premium for smailer vessels is substantially reduced. The much shorter transport versus the haul from Tampa and the greater availability of smaller vessels in Asia reduces the rate differential for small vessels sailing directly from non-regional ports, particularly Tampa. 
idola 3: Estinateo landeo Costs of onf ano urea at karachi from various Sources

\begin{tabular}{|c|c|c|c|c|c|}
\hline SOLREE & $\angle S A$ & USA & DUREAN & FHILIFFINES & KOKEA \\
\hline FOKi & IAMPA & TAMPAे & AQABEA & IEAEEL & rost \\
\hline VESSEL SIZE & $30,000 \mathrm{NT}$ & $15,000 \mathrm{si}$ & $15,000 \mathrm{KT}$ & 15, 000 & $15,000 \mathrm{MT}$ \\
\hline
\end{tabular}

\begin{tabular}{|c|c|c|}
\hline \multicolumn{3}{|c|}{ UREA } \\
\hline$\angle S A$ & $A B U[\mathrm{HABI}$ & INOONESIA \\
\hline RENAI & AL RUWAIS & ACEH \\
\hline $15,000 \mathrm{KT}$ & $15,000 \mathrm{MT}$ & 15,000 MT \\
\hline
\end{tabular}

BULK

$\begin{array}{rrrrr}\$ 200 & \$ 200 & \$ 210 & & \$ 210 \\ 30 & 54 & 15 & 18 & 18 \\ 10 & 10 & 10 & & 10 \\ 3 & 3 & 3 & 3 & 3\end{array}$

$\$ 130$

BAGGEO

AN FREIGHT

GING COST

ARING \& FOFERATẼNG

ON

OARO INLENS

ANNSFOKT

$\begin{array}{lllll}\$ 249 & \$ 267 & \$ 238 & \$ 246 & \$ 241 \\ 36 & 54 & \mathrm{~N} / \mathrm{A} & 18 & \mathrm{~N} / \mathrm{A} \\ \$ 285 & \$ 321 & \mathrm{~N} / \mathrm{A} & \$ 254 & \mathrm{~N} / \mathrm{A}\end{array}$

$\$ 60$

$\$ 150$

$\$ 150$

18

20

$\$ 10$

20

3

3

3

3

ON

BUTTOM

ON BOARD

USAID

JES

$\$ 285$

\$BZ NIA

Ni $\hat{A}$

$\$ 273$

N/A

$N / A$

TES: L. FOE bulk prices derived fron GREEN MARKETS. Septenber 12, 1989.

2. Eagging, clearing ano forwarding costs from FID. 
Moreover, the differential for tagging and handling fertilizers purchased from the Asian producers is only $25 \%$ to $55 \%$ of the differential required by $U .5$. producers ( $\$ 10$ per MT $v 5 \$ 45$ ) and European sources (\$10 per MT vs \$30) see Subsection $D$ below for a discussion about bagging operations at Fort of tarachi and other third country iocations, and their corresponding costs.

While the price of DAF is closely linked to the FoB bull: price established at Tampa, urea prices from Asian producers also terid to vary in accordance with regional supply/demand requirements, and therefore are not so tightly linked to other international prices. Landed costs at rarachi will generally be lower for urea produced by Asian suppliers than for other international producers, whether or not shipment is by small vessels. The smaller the shipment the greater the advantage as in the case of DAF'.

See Table \#S for estimated landed costs from several international sources.

S. Sourcing in Fatistan and Afghanistan

\section{a. Fabistan}

The annual urea production capacity of the six producers in Fakistan is shown in Annex \#5. The production from these sources is currently in balance with domestic consumption, but is expected to fall below total consumption in succeeding years at a rate of about $10 \%$ per year until new plants are built.

The 10,000 to 15,000 MT of urea required for Afghanistan in 1989 is less than $2 \%$ of current annual production in Fal:istan, and with the cooperation of the GOF, can easily be purchased from Falistan producers with little effect on Fakistan supply/demand and future urea imports. One of the producers

Fauji Fertilizer Corporation (FFC), has expressed willingness to supply the entire quantity.

benefits:

Sourcing urea in Fakistan would have the following

- provides the lowest practical price at railhead in Peshawar and Chaman;

- allows synchronization of shipments to railhead with cross-border distribution thus minimizing storage at railhead;

- reduces bag damage and handling loss:

- would facilitate adjustments in the amount lifted to meet changing conditions and requirements in Afghanistan. 
While DAP is not produced in Fakistan, FID has continuously imported large quantities for a number of years including substantial quantities from the U.S. under USAID financing. The Frovincial Government marteting agencies and the major producers maintain large stocks of DAF in many up-country locations at all times. FFC has suggested they could supply the Afghan requirement from their up-country stocks under an arrangement whereby FID would subsequently replace the quantities lifted.

We have not specifically explored the possibility of purchasing the Afghanistan requirement from frovincial stocks or through FID with the GOF but believe that agreement should be forthcoming, particularly in view of the very modest requirement (only $1 \%$ of imports) and the willingness of the GOF to cooperate in programs in aid of the Afghanistan refugees. The same benefits i isted above for urea would apply to domestic (Fakistan) purchases of DAF'.

The overall costs of fertilizer, delivered railhead are discussed in Subsections $F \& G$.

b. Afghanjstan

There is a urea factory at Mazar-i-Sharif in northern Afghanistan near the Fussian border. The plant is a Fussian designed, reciprocating compressor plant that was put into operation in 1974. The rated capacity of the plant is 104,000 MT per year of prilled urea. The natural gas feed stock: comes from gas wells in close proximity to the plant. While we have tried to learn more about the characteristics of this piant, there appears to be no technical information available in Fakistan at this time.

It has been reported by at least two Afghan sources that the plant is presently being operated at an annual rate of $120,000 \mathrm{MT}$, under fiussian management and heavily manned by Fussian technicians. Over-capacity production in an old plant strongly infers recent modification of this facility by the Fiussians.

One of the sources cited has told us that a recent traveller in the area of the plant reports that bagged urea has been extensively stored under tarpaulins outside the permanent product storage buildings, implying large inventories and high capacity production. It is also reported that some urea has been exported to Fiussia, and it is presumed that these exports have been balanced by import of Russian urea into the Herat area of western Afghanistan. Local urea product has apparently been distributed into the Target Area in the recent past, although the quantities are thought to be small. It is reported that urea is plentiful North of the Hindu kush, partly because the Mujatiadin have waylaid substantial quantities being transported south by truck. 
All the reports about the current production and distribution from this factory are verbal. The high rates of p-oduction reported are consistent with the reported quantities o: fortijian distributod by the otill functioning AFC in the last few years (See Table 1 above). However, the anounts said tc be distributed by AFC in recent years seem to be inconsistant. with the data regarding trends in agriculturai production, yield, manpower and population displacement aeveloped by the Swedish Committee for Afghanistan.

It is our view that the Target Area cannot depend on urea supply from the factory at Mazar-i-Sharif and the full requirement of urea must be imported through or from fakistan in 1989 and probably in 1990.

Fhosphatic fertilizers are thought to have been imported from fol and via filussia. As in the case of urea, it is assumed that little or no phosphatic fertilizers will reach the Target Area from this source in 1989. This may be particularly true vis-a-vis phosphates as they undoubtediy represent grant or soft loan assistance from fiussia.

It is important to understand that both the urea production at Mazar-i-Sharif and the import of large quantities of phosphatic fertilizer into the non-targeted areas of Afghanistan are totally dependent on the continuing direct assistance of the filssians and without this assistance the amounts of fertilizer that might be required to be supplied through fakistan in 1989 and succeding years, necessary to prevent wide spread hunger, perhaps famine, are of the order of $200,000 \mathrm{MT}$. It is doubtful that the Fakistan port, rail and road facilities could handle this additional volume, at least in 1989, and without free access to all areas in Afghanistan from Feshawar and Chaman supplying the entire country would be virtually impossible.

\section{4) International Traders}

$$
\text { It is possible to tender for supply of }
$$

fertilizers through international traders rather than directly with producers. This may, in fact, be the most practical way of tendering if USAID procedures and AID Geographic Code 000 apply. In this case the trader is able to bid and supply on a CIF Karachi basis where most U.S. producers are unwilling to bid directly because:

- Bid and performance bonds are required

o Contracting for freight is difficult 
- Freight cost components are uncertain

Free world tenders for supply should be oper to traders as well as prodicerlexporters, since some producers only bid through traders and trade axport associations.

c. Qcean Freight

1) $\quad$ C $F$ versus FOB ghipments

Fertilizers are frequently purchased on a $C \& F$ or CIF basis and if possible it is recommended that imports into Fabistari for this program should be CIF because:

- FOE purchases require additional effort in contracting for freight and insurance.

o There is virtually no cost advantage in breaking out freight or insurance as separate contracts.

However, procurement under AID Geographic Code oOO will require that purchase contracts be $F O B$ and a separate freight contract be bid. In this case, the tendering procedure for freight contracts is spelled out in detail by USAID and this procedure $i s$ well tinown to FID. Help in preparing a frejght IFB can probably be obtained from FID.

\section{2) Qcean Freight Costs}

Estimated current ocean freight rates for

fertilizer cargoes are shown in Table \#3 above. Fiates have been selected for the ports of Kenai (USA), Tampa (USA), Aqaba (Jordan), Isabel (Fhilippines), Yosu (Korea), Al Ruwais (Abu Dhabi), and Aceh (Indonesia). Urea rates are for bagged cargo (except from kenai), and DAF rates are for bulk cargoes (except from Yosu). The kenai freight includes handling and bagging of urea at ari intermediate point such as Yosu, Isabel or Singapore. DAF purchased offshore is assumed to be bagged in Karachi. The freight rates are indicative only.

\section{Eagging}

Fertilizers must be bagged before transporting within Fakistan and Afghanistan. Almost all bagged fertilizer is handled in $50 \mathrm{~kg}$ woven polypropyline outer bags with poiyethylene free inner liners. USAID has detailed specifications for such bags and these are generaily accepted as a standard throughout the world.

During our discussions with several people and organizations during this study, the luse of smaller bags (e.g. $20 \mathrm{~kg}, 30 \mathrm{~kg}$, $35 \mathrm{~kg}$ ) has been mentioned. Smaller bags would allow easier distribution to remote areas, and also, if 
fertilizers are to be distributed to returnees before departing Faristan, the smaller bags would be more portable. We recominend, however, that tre $50 \mathrm{~kg}$ standard bag should be used for the following reasons:

- Many producers do not have bagging equipment that will handle the smaller bags.

o Costs of bagging, handling and storing increase sharply as the bag size goes down.

- $50 \mathrm{~kg}$ is the size that both Afghan and Fakistani farmers are accustomed to.

$0 \quad 50 \mathrm{~kg}$ bags are easily handled.

It is the FID practice to tender for DAF on a bulk plus empty bags basig and bag all DAF cargoes at berth side in Karachi using portable bag packers. Because of concern regarding moisture pickup and hygroscopicity FID does not bag urea at karachi. All of their urea purchases are on a bagged basis and urea purchases for the Afghan program will necessarily be on the same basis.

Bagging costs vary greatly. The current costs of unloading, loading and bagging into wagons and trucks at karachi Fort is Fis 60 per MT exclusive of bag cost. At the present time FID estimates the differential being paid for bags in the composite buil: with bags price is $\$ .5 .50$ per MT. Total cost for bagging and loading at karachi is therefore about 10 per MT.

Currently in the U.S. the cost of reclaiming bulk product, bags, bagging and bag handling into the hold of a vessel is about $\$ 45$ to $\$ 60$ per MT. The corresponding cost in the Fhilippines or korea is $\$ 10$ to $\$ 1$ i. per MT. The cost of raceiving bull: cargo, unloading, storing, bagging and reloading at Singapore is $\$ 22$ to $\$ 27$ per MT. The same cperation at Antwerp or Fotterdam is about $\$ 2$ to $\$ 36$ per MT. Korea and the Fhilippines also have the capability of receiving bulk cargo, storing, bagging and loading (as opposed to bagging out of their own bull: storage) at a probable additional cost of $\$ 4$ to $\$ 5$ per MT. All of the above estimates include physical losses which can run anywhere from $1 / 4 \%$ to $2 \%$ depending on the complexity and location of the operation.

Other locations where bulk cargoes can be received, bagged and reloaded are Hong kong and Turkey. In the case of Turkey, in recent years large quantities of bagged DAF have been supplied to Iran, FOT the Turleish border, from both DAF factories and bulit unloading/bagging operations in several Turbish ports. Within a few years it seens probable that western and northern Afghanistan wili be supplied from Turbish or Iranida ports aceros the Iran/fifghanistan border. 
The NFDC pubijation "Ferticiaer Handing at harachi Fort and Future Frospect" "May 1980, contains a complete deseription ot the fertijiar bagaing and handilng tacilities at farachi. Fo:t and should be read thorowghy. fidditional cominents however are in oroter.

The Fort of lar ahi often suffers severe congestion and for this reason three berths have been dedicated to fertilizer unloadino. Delay of full cargo fertilizer vessels due to congestion has been minimized in recent years. The fertilizer berths have a maximum draft of 32 feet and a LoA of 560 feet. vessels upto a maximum of 35,000 DWT have been received at these berths.

Based on the NFDC report the present bagging and handling facilities have a peak throughput capability of about 200,000 MT per month. At this level the flil 1989 requirement for Afghanistan could be received and bagged in ail months except December and Jaruary. There is evidence of a minor peak in July which at the volumes contemplated sinould not disturb the orderly handing of the Afghan requirement. The anticipatad levels of throughput at rarachi. Fort for 1989 and 1990 do not appear to be i imited in any way by congestion of the unloading and bagging operations at karachi.

However, if it were necessary to handle the full Afghan requirement of say 200,000 mT through harachi both the domestic supply and suppiy to fifginanistan would be distupted.

F. Injand Freight

\section{Clearing and Forwarding}

Failistanj imports of fertilizer for domestic distribution are handlad out of harachi port by approved freight forwarders. A list of forwarders with fertilizer experience is appended in Annex \#4.

The forwarding operation includes unloading, clearing, wharfage payments, freight contracting, inspection and loading. wharfage and indand treight are either paid directiy or reimbursed to the forwarder. The costs of the forwarding service exclusive of unloading/loading and inland freight but including wharfage is estimated at Fis 50 per MT. If cargo is bagged in Farachi the unloading and loading is covered in the bagging charges set out above. Unioading and loading bagged cargo is estimated at Fis 40 per MT.

The average rate of unloading and bagging fertilizer is about 1 io lit per day. In order to avoid over filling the port transit shed and/or incurring transit shed demurrage it is necessary to ship bagged goods from the port at a rate of around 


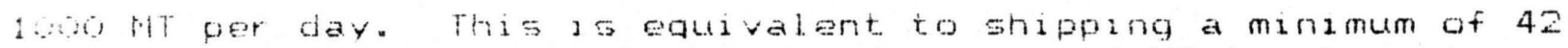
ral waqons (24 Mr per wagon) or 125 truct:s la MT per truct:)

each diy.

The forwardirig agent is normally responsible for l. Jenting for rail wagon from the Fatsstan failway (FF' at the Fort and otherwise ar"anging tructs for the pot tor which cannot te sinippeci by rail.

Indents for rail wagon are filed with FF at 1 asst 24 houts in ddvance of reguirement. Jnless trie indent has priority it is placed in the quete and wagons are suppiied as required or more often as empties are available.

FID has appointed the National Logistic Cell, which is a wing of the Fakistari frmy to handie all cilearing and forwarding of imported fertilizers. NLC also manages the berth-side big packing operation.

Table Habove summerizes all cost to put bagged tertilizers in rail wagons or trurbs at farachi fort, including FOE price, ocean freight, receiving, clearing, bagging an forwarding.

\section{Fiaj]}

The Fakistan fiailway system provides direct broad guage faciliby to railieads rear the Afghan border at Chaman about $75 \mathrm{fm}$ beyond Quetta and at Feshawar. The rail distances from farachi to these two points are about $950 \mathrm{~km}$ arid $1630 \mathrm{~km}$ respectively.

The FFi rail system is generally under utilized by comparisori, for instance; with the Indian fiailways. It is difficult to guage the true capacity of the system. The reasons for the posi performance are not entirely clear but lack of roling stock, and the inefficient management of what is available are major contributors to the problem. The result is frequent delay in supplying wagons at fiarachi fort. In order to expedite shipments to the ffghan border it may be necessary to transport as much as 30 to $50 \%$ of the imported fertilizer by truct. Trucle rates are substantialiy higher than rail rates, so the use of trucks should be confined to the shorter run to Chaman as much as possible.

In order to minimize port handling and inland transport costs it will be necessary to place a manager at taracti during the linlosing of vessels. This person must be delegated the authority to make decisions regaiding the alternate use of rail and truck transport.

The F'F is acclistomed to handing block: or ratie trains. From faracti to Lahore blocks comprise 75 wagons. From Lahore to Feshawar and from farachi to Chaman olocks are 45 wagons. hie larjer blocts are broten at Lahore and the residual wagons are shipped in regular goods trains or are held until a tuil block can be inade up. 
Moving in blocks is the preferred alternative because:

o Transit time is shortened.

- Clearance formalities at railhead are much easier and quicker.

The transit time by rail to feshawar varies between 12 to 20 days and to Chaman by 8 to 15 days.

At both larachi fort and at railhead, wagons attract hourly demurrage beginning six hours after they have been spotted for loading or unloading. Demurrage rates vary with time on the siding arid from station to station.

Currently the freight rate from rarachi to Feshawar is about $F S 500$ per $M T$ and from Karachi to Chaman about fis 300 per MT.

\section{$\therefore \quad$ Truct:}

NLC is responsible for the truct: movement of public sector material from rarachi fort. They operate a fleet of their own trucks mostiy comprised of 20 HT double trailer rigs, and otherwise contract for private carriers when additional tructis are needed.

We were unable to obtain figures for the total number and capacity of trucks operating in fakistan, but discussion with FID, FFC, and importers in karachi indicate that there is no shortage of trucks. Truck transport from karachi to Chaman is estimated to take about 60 hours and to Feshawar about 4 days.

Truck rates from farachi to Fieshawar by privately owned truck:s arranged directly with owners and brokers are about Fis 700 per MT and to Chaman about $F=570$ per MT. The rates charged by NLC are about $50 \%$ higher than normal truck rates or Fis 1050 and $F=560$ per MT respectively.

\section{G. Eorder Terminals}

It will be necessary to operate a warehouse and distribution complex at both the Chaman and Feshawar railheads and possibly other points. While we visited feshawar we were not able to reach dusta and Chaman. Discussions with others currently invoived in fertilizer distribution indicate that our observations in Feshawar hold also in Chaman, and probably the problems observed are more severe, particularly regarding availability of storage.

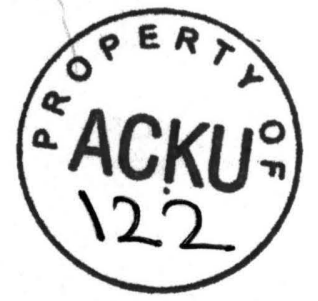


In Feshawar, goods transported by rail can be received at Feshawar Town station or Feshawar Cantt station. Feshawar cantt presently operates the Dry Fort (bonded area) for Feshawar. The Dr. Fort as totaliy inadequate for receipt of block trains of fertilizer. This, coupled with the delay in clearing documents at Feshawar and the probability that customs officials will require that goods for Afghanistan be escorted to the border, means that transporting fertilizers in bond should be avoided at all cost.

Block train shipments can easily be handled at Feshawar Town station and this destination should be used. The station has covered transit storage at trackside equivalent to more than $1000 \mathrm{MT}$ of bagged fertilizer. A block of wagons can be unloaded in two to three days, which means that, using the one day free time in the transit shed, about $300 \mathrm{MT}$ (SB truck loads) per day must be moved out of the station.

To the maximum extent possible shipments from the rail transit sheds should go directly cross-border in order to minimize handling into and out of storage in Feshawar. Intermediate storage is expensive and each handling operation increases bag damage and physical loss. The cost of unloading wagons and loading trucks at the rail transit shed is estimated to be Fis 12 per $M T$. The cost out of the wagon, through transit shed and into storage at Feshawar is estimated to be Fis 40 per MT. Storage and loading out of godowns is estimated at Ris 35 per MT for an average storage time of six to eight weeks, giving a total of Ris 75 per MT if rail shipments are stored in Feshawar.

Truct: shipments from larachi or other Fakistan points of origin will have to be terminated at the railheads. Direct, tailgate transfer to cross-border tructs should be maximized to reduce the costs and losses of going into and out of storage. Tailgate transfer will cost an estimated Fis 10 per MT while transfer into and out of storage, including storage time is estimated to be Fis 50 per MT.

The average terminalling costs at both Chaman and Feshawar, assuming the following:
0
$50 \%$ by truck, $50 \%$ by rail,
0
$50 \%$ of rail shipments loaded directly to cross-border trucks,
0
$50 \%$ of in-found trucis are loaded by tailgate to cross-border trucks,

and using the estimated cost elements above, will be fis 36 per MT. Average costs will be higher if movement by rail is reduced and for a larger fraction of fertilizers is stored in Feshawar. 
The costs at Chaman should be the same.

There are other points along the Fatistan/Afghanistan border where tructs can cross. In particular, the Mujahadin have at least one crossing point south of Feshawar which can apparentiy handle large daily tonnages. We have not tried to investigate this and other such points. Access to railhead and availability of storage at these points should be followed up by more detailed studies to follow.

The peak storage requirements at Feshawar and Chaman are estimated on the basis of the following assumptions:
0
The cross-border fertilizer shipping period is 13 weeks long.
$0 \quad 50 \%$ of all fertilizers will be transportad through Feshawar, the remainder through Chaman.
o $100 \%$ of supply must be imported through karachi.
- Despatch from karachi will be concentrated in a one month period.
- Arrival at Feshawar and Chaman (10,000 MT each) will be more or less uniform over a period of about 7 weet:s.

Despatch to Afghanistan from railhead will take place over a period of about $1:$ weels beginning with the first arrivals by trucks at railhead. An average of 14 trucks per day will be despatched from each railhead during the 13 week period and the peal: storage requirement at each railhead is about 4500 MT.

\section{If local sources (FID, Fakistan urea producers) can be} utilized we estimate that storage at each railhead can be reduced to less than 1000 MT since arrivals at Chaman and Peshawar can be synchronized with cross-border trucks over the full 1 . weel: shipping period.

While it is possible to store $4500 \mathrm{MT}$ of fertilizer at Feshawar in old houses, shops, etc., secure, covered storage of more than 100 to 200 MT capacity is difficult to find. obviously storing in small quantities in 20 or more widely spread points at one railhead would create immense problems of coordination and control. If the storage requirement is more than, say, 1000 MT it would be better to rent a wailed open compound (serai) and store fertilizer in the open under tarpaulins (preferably polyethylene sheet). The same would be true at Chaman.

The terminalling operation at railhead will require experienced supervision (say four including accounting control) and a staff of perhaps 20 local employees (plus guards) at each location. 
Table \#h sets at the average costs of moving fertilizer - rom ter ahi to Chaman and Fershawar, including storage and iosding of truabs destined for fifgianistan. Table \#s summarizes the estimated totai unit costs on board trucks for fertiliaers purchased from U.S. Sources under USAId rules, from the probable lowest cost source, and from stocks in Fiatistan.

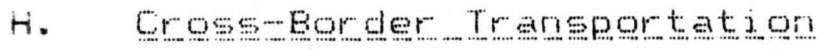

At the present time there is a thiving trade in both directions across the Afghanistan/Fatistan border. Both Afghan and Fakistani trucks are used to haul most of this trade, although traditional methods (camels, horses, mules, etc.) are also used.

Fluch of the torder traffic, perhaps one-half, is presently crossing under import and export documents provided by the kabul. government. The normal border crossing points for the highway beyond Feshawar and Chaman are under the control of the kabul government and fabul government documents are generally required to eross the border. Apparently, some commerce crosses unofficialiy as well, either by forged documents or by bribing guards. Foads have also been cut around these crossings which allow entry without any border formalities (or informalities). it is obvious from discussion with traders, truckers and Ailiance representatives that an increasing amount of materiel is moving over the border without kabul government documents.

Fakistani truck:s move only on the Grand Truck between Feshawar, Jalalabad and fabul and normally do not take cargo for intermediate points on this road. The same apparently holds true between Chaman and kandahar. Afghan trucks can reach anywhere in the country from the two railhealds. As a consequerice fertilizers moving to the Target Area are expected to move entirely in Afghan trucks for possibly trucks owned by the AIME, perhaps without registry), and without kabul government documentation.

A representative of the Alliance has stated that in $1986 / 87$ there were 20,000 Afghan registered trucks having a total capacity 157,000 MT, down from a total capacity in $1978 / 79$ of $170,000 \mathrm{MT}$. Two-thirds of these trucks are privately owned and the remainder are owned by public sector concerns: There is appatently no shortage of fuel; the consultants were tald that nobody walks on the roads any longer, everybody rides.

With an operating fleet this large, there should be no difficulty in moving 20,000 MT of fertilizer cross-border in 1989. About $200,000 \mathrm{MT}$ of wheat, alone, are expected to cross in 1988, an average of 68 truck:s per day.

It is possible to contract for cross-border trucking in Feshawar, Fawalpindi and Lahore. It is also possible to directly hire the daily requirement on an individual basis in the feshawar bazaar, which is what trucking contractors do, in any case. 
Tabie 4: iniano Costs of Delivering Ferticizer at Chaman and feshawar

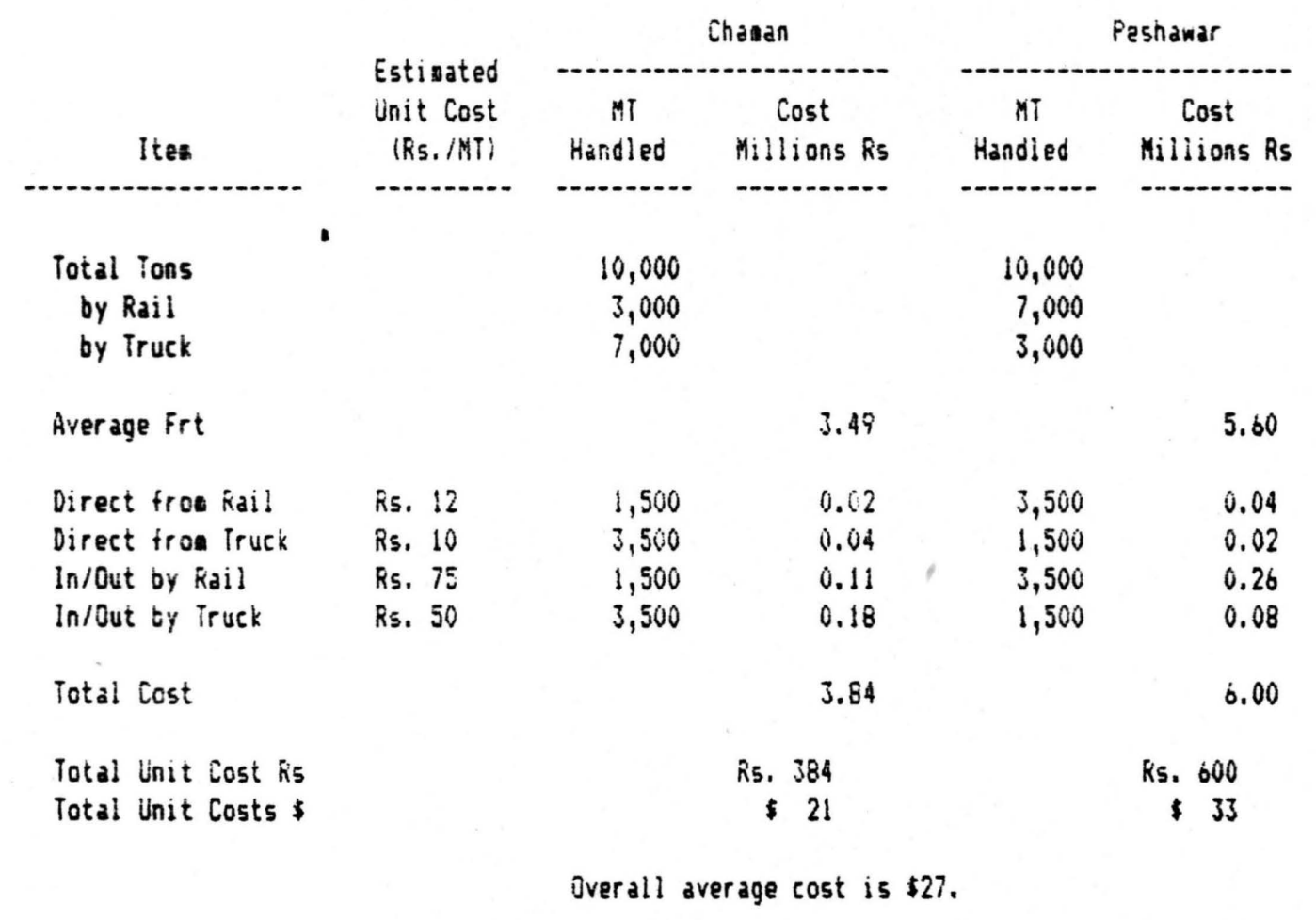


Tacie 5; Total Fertilizer init Costs rü Chaman and Peshawar

i per wi

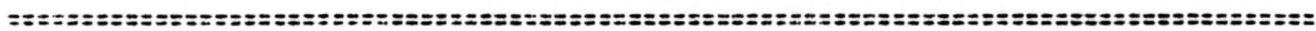

OAP

\begin{tabular}{ccc} 
Ushío & $\begin{array}{l}\text { Lowest } \\
\text { inporied } \\
\text { Cost }\end{array}$ & $\begin{array}{c}\text { Estimated } \\
\text { Pakistani } \\
\text { Source }\end{array}$ \\
\hline Tampa & Jordan & (1)
\end{tabular}

321

238

$\begin{array}{cc}21 & 2 i \\ 33 & 33 \\ 342 & 259 \\ 354 & 27 !\end{array}$

Peshawar

inl and Cos:s

Chatan

Feshawar

Total Cost

Chasan

(1) Lowest iaported Cost plus \$10.

UREA

\begin{tabular}{ccc}
$\begin{array}{c}\text { USAlO } \\
\text { Procbreant }\end{array}$ & $\begin{array}{c}\text { Lowest } \\
\text { Inported } \\
\text { Cost }\end{array}$ & $\begin{array}{c}\text { Estiated } \\
\text { Pakistani } \\
\text { Source }\end{array}$ \\
\hline Kenai & Al Ruwais & (1)
\end{tabular}

273

163

21

33

\begin{tabular}{ccc}
21 & 21 & \\
33 & 33 & \\
\hline 34 & & \\
306 & 184 & \\
& 196 & 206
\end{tabular}

196 
It has also been suggested that the fime maintain and operats its own fleet of trucks. The number of 8 ton truciss required to move 20,000 it of fertilizer during a 13 week period assuming an average 4 day round trip is 110 , a manageable number. Even a small number of trucks, say 25, which could accompany hired vehicles to their destination, could be valuable as a means of verifying delivery. However, the question of registry needs to be examined carefully. Fiegistry in Afghanistan would be by application to an element of the kabul government. Is this acceptable? Can fakistan registered vehicles freely move in Afghanistan? Can unregistered vehicles be driven in Fakistan? 
SEECII $\underline{\underline{N}} \underline{\underline{Y}} \underline{\mathrm{V}}$

\section{DISIEIIEUIION}

\section{A. A_Cross_Border_Distribution_System}

Althqugh both AFC and the Agricultural Bank have survived the war in Afganistan and are operational, their orientation has changed significantly. They are both under the absolute control of the Ministry of Agriculture (MOA), AFC sales are made only to individuals who receive an allocation from the MOA. Unofficial charges of Afs. 20-50 are levied by MOA staff. Under the current regime in kabul, those elements that resulted in AFCC's success in the 1970 s have been eliminated. AFC is now just another bureaucratic institution.

When peace and a new government come to kabul, AFC and the Ag Bank will require total revitalization if they are to play a major role in returning Afghanistan to self sufficiency in food grains.

In any case, neither can now be used in a USAID-financed cross-border program for input distribution or farm credit. Institutional agricultural credit will be of major importance once some of the war damage is repaired and agriculture begins to operate under normal conditions. However, at this point the real need is to make minimal repairs on the irrigation structures and get crops into the ground to provide at least subsistance levels of food for the returning refugees and displaced persons.

The AFC, as operated prior to the war See Annex \#1 was considered to be the most efficient and effective organization of its kind in the coontry. In 1978, the World Bank in its economic report on Afghanistan singled out the AFC/Ag Bank operationa as being the most important factor contributing to food security in Afghanistan.

1. Criteria for an interim Agricultural Inout Mobilization_ Entity (AIME)

The following criteria for the establishment of a distribution entity reflect our understanding of AID/REF's parameters as well as limitations imposed by the current conditions in Afghanistan.

- It is neither appropriate nor desirable to attempt to establish a permanent distribution system. Any mechanism should have as its purpose the interim suppliy and distribution. of fertilizer and other inputs to a target group in Afghanistan. It would be a temporary system. 
The primary beneficiaries will be those displaced Afghans who are being resettled and the returning refugees. Secondary beneficiaries will be Afghan farmers whose operations were only marginally effected by the war, who remained in place and who can buy inputs for cash.

- Cross-border movement of agricultural inputs will be controlled so as to assure they are not being used to support the kabul regime.

- Any distribution mechanism must have the endorsement the Seven Party Alliance. However, none of the Farties nor the Alliance would be directly involved or have direct influence on AIME management.

0

The AIME's primary area of operation would be in a crescent roughly $250 \mathrm{~km}$ inside Afghanistan beginning in the Helmand valley in the south and then north along the Fakistan border to Kunar province.

- The system must be fiscally responsible.

\section{A_Conceptuㅡㄹㅡ_Eramework_for aㅡ_AIME}

Consistant with the above criteria AIME would be created along the 1 ines of the AFC and would be composed of the following elements.

- A Supreme Council (6-10) made up of senior Afghans and representative of $A I D$ and AIME management.

- A four person expatriate management team with operational and fiscal management responsibilities.

- A countrpart Afghan management team recruited to the extent possible from former members of the AFC or current AFC staff now resident in Kabul.

- At least three senior regional managers in Afghanistan possibly in Kandahar, Jalalabad and Ghazni.

- An operating staff at all locations for administration, accounting, inventory control, and warehousing.

- Qffice and warehouse facilities in Peshawar and Quetta as well as office and warehouse facilities in Afghanistan.

- A fleet of approximately 100 trucks of 7 ton capacity and possibly 20 pickup trucks for regional 


\author{
operations within Afghanistan. \\ - A wholesaler/dealer network covering the target \\ area.
}

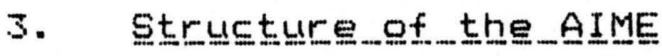

AIME wowuld be a temporary entity structured to deliver agriculture inputs inside Afghanistan targeted for returning refugees and displaced persons yet capable of supply the needs of the total farming community. The principal conentration of effort would be in a crescent shaped area averaging about $250 \mathrm{~km}$ wide inside the Afghan border running from the Helmand valley in the south to Kunar province in the north.

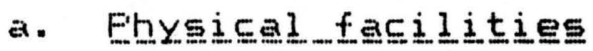

- The AIME's principal office would be in Feshawar with a branch office in Quetta. Both locations would have warehouse facilities for 4-5000 tons of fertilizer, seed, tools parts and other supplies.

- A fleet of 100 trucks of 7 ton capacity would commute between the warehouses in Pakistan and distribution locations in Afghanistan. The trucks would serve as an extension of the warehouse delivering to AIME distribution points, dealers and where appropriat direct to farmers.

- In Afghanistan regional headquarters would be located near the cities of Kandahar, Ghazni and Jalalabad. In addition to office space each regional headquarters would have storage for 1000 tons of inputs sub-region would have storage space adequate to meet local needs.

- To provide mobility to home office, regional and sub-regional personnel vehicles will be required. It is estimated that 20 pickup trucks would be needed.

- Office equipment for all offices.

\section{b. Qperations and Mangagement of ththe_AIME}

USAID, using Handbook 13 grant or normal

contracting procedures, would request proposals from qualified U.S. firms. To qualify a firm, in addition to their technical competence, would denonstrate a level of prior experience and on-board capacity to handle the extra ordinary responsibility of the AIME program. The selected firm, under the terms of the grant agreement or contract, would be directly responsible for all operational aspects of the AIME. The firm would provide: 
- Fiesident (in Falistan) expatriate management with direct operational responsibility and expertise in the following discipline:

-- Managing Director/Frocurement

-- Financial Management

-- Logistics and Warehousing

-- Training

-- Short-term technical specialists

$\circ$

Afghan nationals for management functions and operating staff, to the extent possible recruited from current and former AFC personnel. All such staff would be cleared by the Seven Farty Alliance.

- In-country and home office procurement of all commodities and supplies as provided for in the grant agreement or contract, or financed by other mechanisms (including the CIF).

- Financial and end use accountability for all AIME activities. This would include printing and controlling input coupons but not distributing them.

- Expertise and home office support to mobilize the AIME and expedite the start up process.

\section{Eunction of the AIME}

The principal-purpose of AIME would be to procure, import, warehouse, transport and distribute inputs across the Afghan border through a private retailer network. The secondary purpose would be to upgrade the training of former AFC employees and train new employees on the job who may in the future become employees of the new AFC.

As Afghanistan returns to its pre-war status, is pacified and installs a popular form of Government in Kabul, the AIME could, with all its records, accounts and assets, be merged with the AFC in Kabul or even become the new AFC.

In the meantime AIME management would proceed with the process of activating AIME along the lines of the following scenario:

- locate facilities and establish headquarters in Feshawar;

- recruit initial Afghan staff;

- refine commodity schedules and initiate procurement actions: 


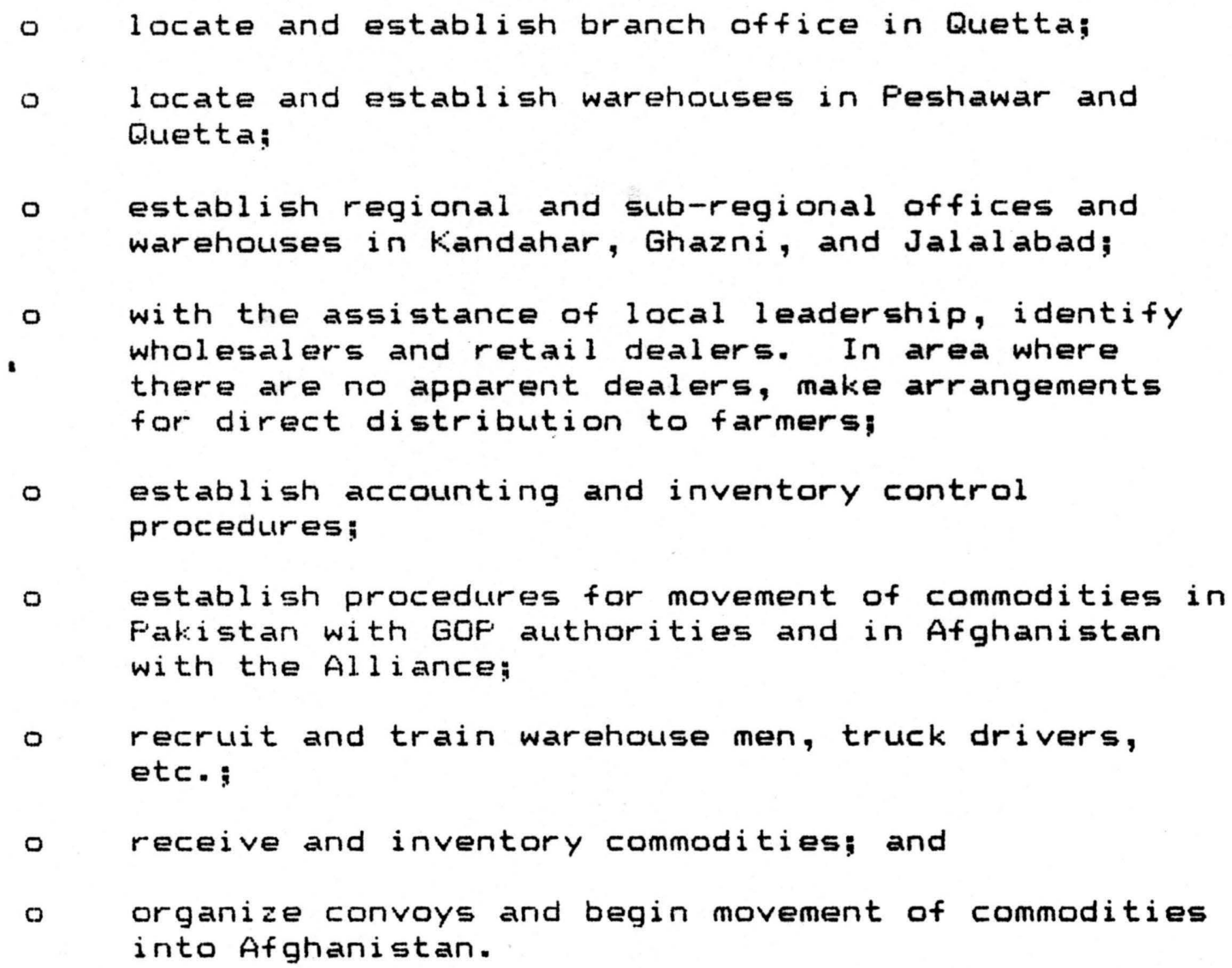

3. Marketing and the_Iarget_Groule

AIME would sell products through its wholesaler/dealer organization or directly to farmers in areas where there are no dealrs. Sales would be made at fair market prices say twice the current official prices to anyone who has the cash to pay. Reflows from these sales would be used to offset AIME operating expenses.

Target groups of returning refugees and displaced farm families could purchase with coupons which would be redeemable in agriculture inputs through the dealer network or directly to AIME. Dealers would use the coupons to purchase more fertilizer or other inputs from their wholesalers or AIME. Sales commissions to these dealers would be paid in cash.

Coupons allocation would be made by the AIME Supreme Council (described below) and could be distributed to the target group through various means:

\footnotetext{
- A non-government organization developed specifically for this task.

- The Seven Farty Alliance.

- Local commanders in Afghanistan.
} 
- Handed directly to retaining refugees.

A coupon system would require close monitoring and supervision to assure that the target group is indeed being served and that cominodities remain in Afghanistan.

The use of coupons provides a great deal of flexibility. They could be:

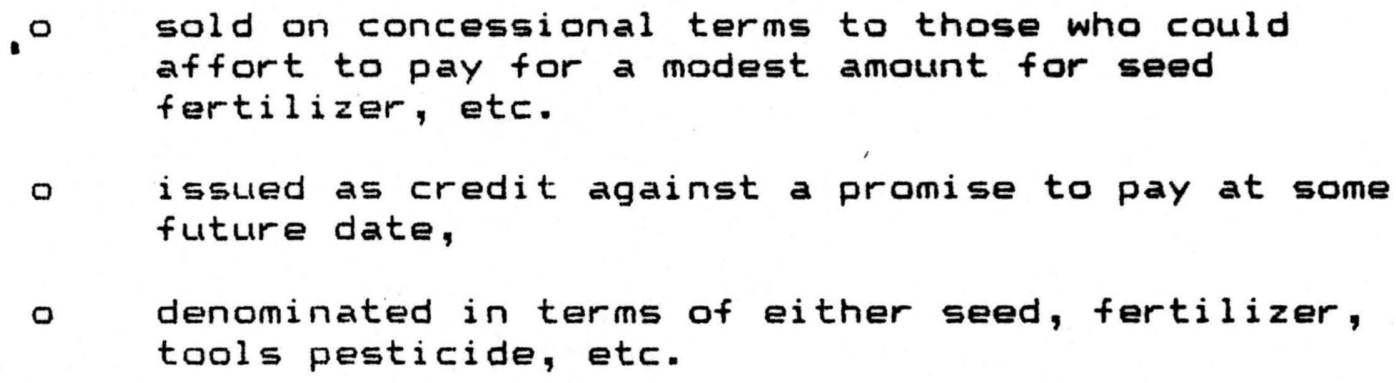

Afghan farmers are accustomed to the use of coupons as means of targeting credit. This method was successfully used by $A F C$ and $A g$ Bant during the 1970s. The use of coupons affords the oportunity to strike a balance between cash sales and grants or vary the level of subsidy.

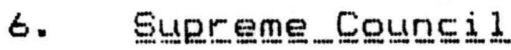

A Supreme Council would be required to set policy relating to input distribution. Such a council would be comprised of senior Afghans of the character and stature Dr. Abdul Wateil and Dr. Azam Gul who would be acceptable to the Seven Farty Alliance and who have the respect of the Afghan community. USAID's interests should also be represented on the council. The managing director of AIME should be an ex-officio member.

The council would set fertilizer prices; recommend allocations when necessary; determine which groups or individuals would be recipient of coupons and address other policy issues. The council would not, however, have direct operational control of the AIME. 
Annex \# 1

Fage 1 of 3

\section{The Afghan Fertilize Comeany}

The introduction and adoptation of $\mathrm{High}$ Yielding Varieties (HYV) of wheat in Afghanistan during the mid 1960 s created a demand for fertilizer that exceeded the capacity of the Government of Afghanistan (GOA) to satisfy. Froblems inherent whithin the system inhibited distribution and generated handling and inventory losses in excess of $20 \%$. The Ministry of

Agriculture and Irrigation (MAI) was the principal GOA instrument chosen to import, store and sell fertilizer directly to farmers for cash. A credit sales system was administered by the GOA Food Deparrtment which proved unable to collect more the small amounts of the credit issued. In response to USAID's urging the GOA/MAI agreed to establish a system which provided selected village dealers with consigned inventories of fertilizer and deferred payment on slaes until harvest time. The system was an improvement over the MAI direct sales approach and worked well at first. The system, however, soon bogged down as the MAI established a sales margin that was inadequate to cover normal handling loss and provide even a small profit. Supplies normally fell short of demand during peak use periods. The abnormal handling loss experienced by the MAI coupled with an excessive subsidy represented a severe strain on the GOA budget.

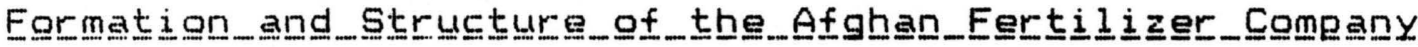

In 1970 the faiure of the system was acknwledged by some members of the GOA and in the spring of 1971 the Cabinet endorsed "in principle" the desirability of shifting the responsibility of fertilizers distribution to the private sector. In May 1971 USAID offered to finance the projected fertilizer short-fall if assurances could be provided that it would be distributed in accordance with the Cabinet decision. The GOA rejected the offer.

In July 1971 the effects of two years of drought spurred the GOA into taking emergency action to ensure that wheat production for the 1972 crop would be maximized. Dr. Abdul Wakil was appointed Minister without portfolio and charged with the responsibility for fertilizer supply and distribution as well as the expansion and reorganization of the Extension Service. The "Emergency Fower" invested in Dr. Wakil allowed for shortcutting many of the inhibiting bureaucratic procedures and provided for an objective approach to fertilizer distribution. An objective approach coupled with Ag Bank's emergency credit system, which provided credit to individual members of village groups who undertook the responsibility jointly and individually to repay the credit, resulted in unprecedented levels of fertilizer and seed distribution throughout Afganistan.
a record breating wheat harvest in 1972.

This effort resulted in 
Annㅡㅡㄹㅡ. \#1

Fage 2 of 3

While the GOA recognized that this emergency system could not be used perinanently it was nonetheless a graphic demonstration of what could be done. An objectively oriented group of Afghans unencumbered by Bureaucratic roadblocks could indeed bring unprecedented quantities of fertilizer to an unprecedented numbers of farmers. The situation was thus ripe for another look at an alternative distribution system.

Dr. Wakil organized a working party (later known as the "Wakil Fertilizer Committee") to explore in greater detail how a private distribution system could, under Afghan conditions, be organized. The committee Chaired by Dr. Wakil was composed of representatives from: The UNDF financed Ag Bank expatriate management team, an American advisory team financed by AID to assist in private industrial development, and AID. The committee produced and forwarded to the GOA Cabinet the "Wakil Report" which proposed the formation of a private joint stock company called the Afghan Fertilizer Compnay (AFC). The company which was. to be responsible for the procurement, importation, storage and distribution of fertilizer would be $51 \%$ owned by the Ag Bank with the balance of the stock made available to qualified, financially sound private wholesalers. The Cabinet accepted the major recommendation of the "Wakil Feport" and initiated action by releaving the MAI of all responsibility for fertilizer; appointing a GOA fertilizer policy committee chaired by Dr. Wakil with members from the Ministries of Finance, Planning and Agriculture to set fertilizre price and deal with othr policy issues; authorizing the Agriculture Development Bank to form the AFC; and finally instructing the Ministryof Flanning to request AID financed assistance to cover the cost of a three year supply of fertilizer and a 9 man expatriate management team for AFC.

In October 1972 AID approved a $\$ 20 \mathrm{mill}$ ion loan to support AFC. Ey late November a management team was selected and in January 1973 the team arrived in kabul. The team had direct operational and financial responsibility for AFC and immediately began to select management trainees/counterparts and staff for the AFC.

The AFC became operational in March of 1973. AFC wholesalers began establishing dealer networks in all provinces of Afghanistan. By June product was moving through the system and AFC was launched. The July 1973 coup deposed the King and brought with it a new Government. The new Minister of Agriculture immediately attempted to take over AFC and place reponsibility for fertilizer distribution once again under the control of the MAI. USAID vigorously apposed such a move holding that the loan agreement would be breached and that the second tranche of fertilize (some $12 \mathrm{million}$ ) would be lost to Afghanistan. 
Anne트료 1

Fage 3 of 3

The issue was not immediately settled and AFC remained operational as originally designed. Fall 1973 fertilizer sales were the highest on record and handling loss were reduced from $20 \%$ to less than $0.5 \%$.

Negotiations continued with the MAI over the status of AFC and a consensus was reached in the $f$ all of 1974. AFC would remain intact but the expatriate would become advisors and their Afghan counterpart trainees would become the managers and operators. In addition the new Government felt that it was inequitable for wealthy merchants to make a profit by hanling a strategic commodity like fertilizer. USAID concented to the GOA position but insisted wholesalers who had invested in AFC be reimbursed.

The AFC continued to operate efficiently albiet with a reduced capacity to handle product even with a significantly larger staff.

During the period 1973 to 1978 fertilizer sales increased at the rate of approximately $15 \%$ per year with more than 80,000 tons sold in 1978. AFC's capacity to efficiently procure, import, warehouse and distribute fertilizer coupled with effective credit supplied by Ag Bank's national system lead the country to selfsufficiency in food production in 1978. 


\section{U. S. Froducers/Exporters of DAF and Urea}

\section{DAE}

Agrico Chemical Co. (Freeport) 1615 Foydras $S t$.

New Orleans, LA 70112

CF Industries, Inc.

Salem Lake Drive

Long Grove, IL 60047

CONSEFV, InC.

P.O. BOK $\$ 14$

Nichols, FL 35863

Kaiser Estech

Division of Vigoro Ind., Ine.

F.o. Box 246

Savannah, GA $\$ 1402$

Mobil Mining \& Minerals Co.

F.o. BOK 26683

Fichmond, VA 23261

Occidental Chemical Corp.

Agricultural Froducts Group

F.O. Bo\% $\$ 1597$

Tampa, FL 3\$631-\$597

Foyster Company

F.0. Box Drawer 1940

Norhald, VA 2SEO1

Texasgul $f$

Morehead, North Carolina
Ureeㅗ

Agrico Chemical Co. (Freeport) 1615 Foydras St.

New Orleans, LA 70112

Columbia Nitrogen Corp.

F. 0. Box 1483(13)

Augusta, GA 30913

First Mississippi Corp.

Bok 1249

Jackson, MS $\$ 9205$

Mississippi Chemical Corp.

F.0. BOX 388

HWy. 49E

Yazoo City, MS 39194

Olin Corporation

F.o. Box 991

Little Rock, AR 72203

Dccidental Chemical Corp.

Agricultural Froducts Group

F.o. Box $\$ 1597$

Tampa, FL 33631-3597

Union Oil Co.

Kenai, Alaska 
Other Free wor id Froducers Exeorters of DAF and Urea

\section{Country}

ndonesia Indonesia Indonesia Indonesia Malaysia U.A.E. Qatar

Saudi Arabia Kuwait

Fhilippines

Korea

Jordan

Morocco

Naine

Fort

Urea $(A s i$ a Qn $I y)$

Pusri

Kaltim

Kujang

Asean Aceh

Aseari Bintulu

ADNOC

SAFCO

FiIC

\section{$D A F$}

Fhilippine Fhosphate Fertilizer Corp. Namhae Chemical Corp. Jordan Fhosphate Chemicaj. Co.
(Sumatra)

Bontong, Kalimantan

(Jaba)

Aceh, Sumatra

Al Finwais, Abu Dhabi

Kuwait \& Bahrain

Isabel, Leyte

Yosu

Aqaba

Casabl anca 
Haji Mumtaz Goods TF'T Co.

Niaz Muhammad \& Brothers

Bashir Síddiq Goods

Transnational Limited

New Malik Goods

Azad Chaudhry Goods

New Hakeem \& Company

Ashfaq Goods Transport

Black Hawt: Carriers (FVT) Ltd.

World Wide Carriers

Murad \& Company

M. B. Enterprises (F'TV) Ltd.

Tariq Associates Limited

Source: FFC 


\section{Falistan Froducers of Ureaㅡ}

\section{Name}

\section{Exxon}

Fak-Saudi

Fauji Fertilizer Corp.

Dawood-Hercules

Fak-Arab

Fak-China

\section{느오aㅓ으므}

Dharki, Sind

Mirpur Mathelo, Sind

Goth Macchi, Funjab

Lahor, Funjab

Multan, Funjab

Hazara, Funjab

\section{드르크도트y}

\begin{tabular}{|c|c|}
\hline 230,000 & MT/year \\
\hline 554,000 & $"$ \\
\hline 570,000 & $"$ \\
\hline 346,000 & $"$ \\
\hline 100,000 & $"$ \\
\hline 99.000 & $-" 1$ \\
\hline
\end{tabular}




\section{Eersons Contacted by The Chemonics Fertilizer Team}

\begin{tabular}{|c|c|c|}
\hline Name & Iitie & Organization \\
\hline Tahir Saleem & Froject Director & $\begin{array}{l}\text { National Fertilizer } \\
\text { Development Center, } \\
\text { Isl amabad }\end{array}$ \\
\hline Juan I. de la Vega & Froject Manager & FAO/NFDC, Isl amabad \\
\hline Whitney Yelverton & Assist. V.P. & $\begin{array}{l}\text { The Fertilizer Institute, } \\
\text { Washington, D.C. }\end{array}$ \\
\hline David Garner & Chief of Party & VITA, F'eshawar \\
\hline Abdul Waki i & Chief Tech. Advisor & VITA, Peshawar \\
\hline Faraque Assam & & Seven Party Alliance \\
\hline Azim Nasser Zia & Member & $\begin{array}{l}\text { National Islamic Front of } \\
\text { Afghanistan }\end{array}$ \\
\hline Homer Hepworth & Wheat Ereeder & CIMMYT, Mexico City \\
\hline Imtiaz Ahmad & Dep. Fort Manager & Fakistan Railrays, Peshawar \\
\hline Ishtiag Ahmad & Managing Fartner & Al-Mushtag \& Co \\
\hline Ray Fort & Fegional Director & FAO/Isl amabad \\
\hline$A z a m$ Gul & Director & $\begin{array}{l}\text { The Swedish Committee, } \\
\text { Feshawar }\end{array}$ \\
\hline Rahim Chaudhry & Sr. Salesperson & $\begin{array}{l}\text { Fauji Fertilizer Co. Ltd., } \\
\text { Lahore }\end{array}$ \\
\hline Saed Mohsin Fizvi & Director & $\begin{array}{l}\text { Federal Directorate of } \\
\text { Fertilizer Import (FID) }\end{array}$ \\
\hline Thomas olsen & Ag. Economist & USAID/Fakistan \\
\hline Robert Armstrong & Ag. Economist & AID/W/ANE/RD \\
\hline Gary Lewis & Ag. Dev. Officer & AID/REF/ISL. \\
\hline John Gunning & Frog: Officer & AID/REF/ISL. \\
\hline Henry Cushing & Area Fiep. & AID/REF/Feshawa \\
\hline Albert Nehoda & Field Officer & AID/FEF/Feshawar \\
\hline
\end{tabular}

